\title{
Analysis Potency of Character Education Values in "Kebo Ketan" Ceremony as a Source of Social Studies Learning
}

\author{
$1^{\text {st }}$ Parji \\ Universitas PGRI Madiun \\ Madiun, Indonesia \\ parji@unipma.ac.id
}

\author{
$2^{\text {nd }}$ Yoga Ardian Feriandi \\ Universitas PGRI Madiun \\ Madiun, Indonesia
}

\author{
$3^{\text {rd }}$ Diah Rokhana Maskunati \\ MTs Negeri 5 Ngawi \\ Ngawi, Indonesia
}

\begin{abstract}
This research aims to reveal the values of character education in "Kebo Ketan" ceremonies, which can then used as a source of learning for social studies subjects. This type of research is qualitative ethnographic research. The research location is Sekar Alas Village, Widodaren District, Ngawi Regency. The primary data source in this research was the result of interviews with the community who conducted the "Kebo Ketan" ceremony ( 3 people), and secondary data was the result of interviews with visitors and residents of Sekar Alas Village (3 people). Data Collecting through observation, interviews, and documentation. The results showed that the "Kebo Ketan" ceremony had the potential of character values such as religious, hard work, care for the environment, tolerance, love for the homeland, and responsibility.
\end{abstract}

\section{Keywords: character education, Kebo Ketan}

\section{INTRODUCTION}

Social studies is a learning that is closely related to the environment, especially the social environment. Therefore, social studies learning should make optimal use of environmental potency to make it more meaningful. At this time it was found that Social Studies Learning tended not to be contextual. The potential of the local environment such as local culture is not used optimally in the learning process. The character is one of the most important goals of social studies education. Many educational goals in various countries include character elements in them [1]. At present social studies learning tends to only prioritize the development of intellectual aspects only, with textbooks being the main learning source [24]. As a result, character education which is one of the goals of Social Education has not optimal.

Local Culture becomes a means that can use in character education. Through local wisdom/culture, the community can learn the values of the original character of their ancestors, so that despite the very rapid progress of the people the community will not leave their identity [5-7] [2] [3] [4]. Kebo Ketan ceremony is a series of traditional events carried out by the people of Ngawi Regency regularly to commemorate the Birthday of the Prophet Muhammad SAW; this ceremony is acculturation of Javanese culture and Islamic culture that is developing in Ngawi district (Interview with the Ngawi village community March 20, 2018). Acculturation of Hindu culture and Islam in Java often occurs because of the influence of the Hindu reform movement, as a result of the introduction of Islam into Java[8,9] [5] [6]. Something similar also happens in other cultures such as puppets, dance, and slametan reading[10-13] [7] [8] [9].

The "Kebo Ketan" ceremony initially originated from a folktale about humans marrying a fairy and held by residents of Sekar Alas and Sekar Putih villages accompanied by nongovernmental organization "Kraton Ngiyom" and Ngawi Regency Government (Interview with the Ngawi village community March 20, 2018). This celebration expressed in contemporary Javanese culture. The event was an expression of cultural arts which packaged in the form of "Happening Art." The art combined with elements of religious value, where the implementation is part of Maulid Nabi Muhammad SAW. The cultural expression at the ceremony was carried out with a drama performance with stories of humans marrying fairies.

The narrative developed in the drama began with the human story "Ibnu Sukodok" married to "Peri Setyowati", a fairy who guarded forest areas and springs ("Sendang Marga" and "Sendang Ngiyom") in the village of Begal. As a fairy, Setyowati asked "Ibn Sukodok" to help him replant the forest that used to contain old trees that were lost due to illegal logging. Human and fairy marriage missions are not sex, not assets, or support polytheism, but, have the goal of saving culture and ecology on Java, especially in Begal forest, in Ngawi District.

As a continuation of the drama narrative, Man marries the fairy, then continues with the Kebo Ketan Ceremony, as a manifestation of human commitment to protect the environment. The choice of kebo animals themselves has meaning, which is kebo which is an animal loyal to its owner and always wants to 
work hard to help humans to cultivate nature, such as plowing fields. Whereas Ketan was chosen because it symbolizes a harmonious relationship between humans and nature, a harmonious relationship that is meant by humans managing, and preserving the land and being planted with sticky rice which in turn humans get food in the form of sticky rice (Interview with the Ngawi village community March 20, 2018)

Outline of the "Kebo Ketan" ceremony is a procession and "sacrifice" of a symbolic buffalo made of glutinous rice. The procession also accompanied by various kinds of local art from Ngawi. The series of events began with the "wiwitan" procession (beginning), the procession was marked by "Nandur Ketan" and "Nandur Kebo Ketan" ceremony by the villagers, sticky rice used for the manufacture of buffalo, and at night "Bancakan" was carried out. The procession continues with the making of replicas of buffalo animals in special buildings erected in forests and illuminated by lights so that at night the silhouettes will look like shadow puppets.

On the first day of the ceremonial procession, the "Kebo Ketan" was released from his cage and paraded $9 \mathrm{~km}$ with the "Trethek" music group to Sendang Margo to be carried out, given an audio-visual frame of the sacred dancers. It is said that in the Neolithic period it was interpreted that "the ancestors and gods descended from heaven to witness and pray". Then Kebo will be paraded to the place where the sacrifice is made, after the prayer is read then the slaughter of the Kebo Ketan is done. Tens of liters of blood made from red sugar spilled onto the ground, then the ceremony participants will share the food to eat together. No less important is that before, during, and after the kebo ceremony the sticky rice takes place, the location of the ceremony is always clean because there are volunteers from the ants, they are an important part of the art ceremony held. These volunteers are on duty during the ceremony by keeping the ceremony site clean of rubbish and reprimanding visitors who throw litter.

\section{METHOD}

This research uses a qualitative ethnographic approach, which is more concerned with the depth of discussion and meaningful information, as well as a complete picture of the circumstances and events and values of the Kebo Ketan ceremony in Sekar Alas Village that can build the character education of students, as well as a source social studies learning.

The research conducted in Sekar Alas Village, December 2017-2018. Primary research sources were information from the ceremonial actors, and secondary data sources, namely information from residents and ceremony visitors who witnessed but were not actively involved in the ceremony. And from relevant books, journals, and literature. Data collection uses observation, interview, and documentation techniques. For data validity, researchers use source triangulation, which is a data collection technique that is combining various data collection techniques and existing data sources.

\section{RESULTS AND DISCUSSION}

The values that arise from the implementation of the Kebo Ketan ceremony are good, decent, appropriate, right, beautiful, valuable, useful, useful, and desirable values for human life in society. The values that can take from the Kebo Ketan ceremony (Table 1)

TABLE 1. THE POTENCY VALUE OF THE CHARACTER IN THE KEBO KETAN CEREMONY

\begin{tabular}{|c|c|}
\hline Value & Description \\
\hline Religions & $\begin{array}{l}\text { This character is reflected when the salvation \& "Bancaan" event takes place; this evidenced by the prayers offered to God so } \\
\text { that each year is given welfare and ease in managing the natural potential in the Ngawi region. Also, in the practice of practicing, } \\
\text { the guidance of religious worship, especially Islam, such as reciting prayer. The "Bancaan" correlation with the religious } \\
\text { character also evidenced by various other studies such as [14-16] . By seeing this procession, it hoped that it will inspire and } \\
\text { provide guidance for students to always be cautious of their respective religions, by Indonesian ideology, whose wrong } \\
\text { principles consist of "God". }\end{array}$ \\
\hline Hard-Working & $\begin{array}{l}\text { The potency for the hard-working character seen from the symbol of Kebo (buffalo) that used, Kebo is a symbol of the hard } \\
\text { worker. Kebo in the Javanese community is used to help the agricultural sector such as plowing fields, taking milk and even } \\
\text { using the meat for consumption. From that, the community can imitate the ethos of work done by buffaloes, without expecting } \\
\text { Buffalo to continue working hard to help the farmers. }\end{array}$ \\
\hline Nature conservation & $\begin{array}{l}\text { Environmental problems have become a multidimensional problem, and become a serious problem experienced by } \\
\text { citizens. Issues will worsen if they not overcome. Moreover, the population will continue to increase dramatically every } \\
\text { year. Cogan \& Dericotstates that the population of the earth will increase dramatically in } 2025 \text { which is to } 8 \text { billion [17]. } \\
\text { The growing population also indicates that the present period of society has entered the Risk Society phase, as stated by } \\
\text { Beck [18], namely people living with risks as a result of modernization and technology. From that fact back to local } \\
\text { wisdom becomes an appropriate alternative solution, during the Kebo Ketan ceremony the main value taught about the } \\
\text { environment. This can see from the myth of holding fairy rabbis who then asked humans to protect the environment. In } \\
\text { addition to the Kebo Ketan tradition also begins by planting sticky rice, and then made buffalo shape and filled with } \\
\text { brown sugar, which is where the buffalo is compared to cut, and the blood flows to irrigate the barren lands. }\end{array}$ \\
\hline Tolerance & $\begin{array}{l}\text { Interfaith conflicts often occur in religious life in Indonesia, one of which occurs because of a mindless attitude. It is an attitude } \\
\text { that is indifferent and does not want to gather with other different groups [19]. For this reason, there is a need for cross-cutting }\end{array}$ \\
\hline
\end{tabular}




\begin{tabular}{|l|l|}
\hline \multicolumn{1}{|c|}{ Value } & \multicolumn{1}{c|}{ Description } \\
\hline & $\begin{array}{l}\text { affiliations. Thus the potential for existing conflicts can be muted due to the existence of cross-cutting loyalty from differences } \\
\text { that exist in society [20]. From this, it can be understood that any cross-cutting affiliations accompanied by cross-cutting } \\
\text { loyalty. } \\
\text { Creating a state of society that crosses cutting and cross-cutting loyalty is very important, we can see from J.S. Furnivall, who } \\
\text { said that a pluralistic society like the one in Indonesia is a society that adheres to a variety of value systems and becomes its } \\
\text { parts. So that the community members lack loyalty to society as a whole, lack cultural homogeneity or even lack the basics to } \\
\text { understand each other [21]. }\end{array}$ \\
\hline $\begin{array}{l}\text { Preserve regional culture and } \\
\text { love of the country }\end{array}$ & $\begin{array}{l}\text { In the implementation of the "Kebo Ketan" Ceremony filled with various kinds of arts from various existing traditions, it also became } \\
\text { a good medium for introducing regional culture to the community. In the current era of globalization, people experience a cultural } \\
\text { crisis. This can be seen from the habits of Indonesian people who prefer outside cultural values compared to local culture [22]. }\end{array}$ \\
\hline $\begin{array}{l}\text { Discipline and } \\
\text { Responsibility }\end{array}$ & $\begin{array}{l}\text { The volunteers of the children who were invited to join in the Kebo Ketan ceremony, not only as cleaning rubbish, but also } \\
\text { trained to be independent and disciplined. }\end{array}$ \\
\hline Spirit of nationality & $\begin{array}{l}\text { During the ceremony, all those present began from the Regent of Ngawi, officials, supporters of the event, the army of ants, } \\
\text { as well as visitors who watched the program to sing the song Indonesia Raya complete three stanzas, with the tempo of the } \\
\text { march happy as the original during the struggle for independence, so foster a loving spirit of the homeland. }\end{array}$ \\
\hline
\end{tabular}

The Kebo Ketan ceremony itself can potentially be a source of social studies learning because it is a scientific teaching material based on research, as well as a more concrete form of presentation of information and teaching materials because based on facts. The source of learning is one important thing to support the success of an educator and students in carrying out learning activities, especially in school. Sources of learning can come from outside a person (students) and that allows (facilitates) the occurrence of the learning process.

\section{CONCLUSION}

The Kebo Ketan ceremony is a traditional art that is carried out as one of the series of prophets of the Prophet Muhammad SAW. Kebo Ketan ceremony originated from folklore about humans who married fairies; this marriage has the main purpose of preserving nature, especially forests that have suffered tremendous damage.

By carrying out this ceremony, the community can strengthen social cohesiveness, because in the ceremony the community experiences cross-cutting affiliations and crosscutting loyalty. Cross-cutting affiliations and cross-cutting loyalty can occur because the communities of various affiliations and differences that work together and work together, mutually reduce the ego and emotions to maintain mutual unity, then the importance of maintaining harmony and balance between humans and the natural environment, and do not forget to always express gratitude and also prayer to God.

The potential for character education in the Kebo Ketan ceremony can see from the various values that arise in its implementation; the values are religious, hard work, caring for the environment, tolerance, love for the country, and responsibility. The Kebo Ketan ceremony is also suitable to be used as social studies learning because the form of presentation of information and teaching materials is more concrete because based on facts in the surrounding environment.

\section{REFERENCES}

[1] Schuncke G M 1988 Elementary Social Studies: Knowing, Doing, Caring (Macmillan Pub Co)

[2] Sari S N, Rachman M and Utari I S 2015 Model Penanaman Pendidikan Karakter Berbasis Nilai-nilai Kehidupan Sosial pada Mata Pelajaran IPS di Sekolah Agama J. Educ. Soc. Stud. 4 36-42

[3] Purnomo A, Muntholib A and Amin S 2016 Model Pembelajaran Ilmu Pengetahuan Sosial ( Ips ) Pada Materi Kontroversi ( Controversy Issues ) Di Sekolah Menengah Pertama ( Smp ) Kota Semarang 33 13-26

[4] Alexon and Sukmadinata N S 2010 Pengembangan model pembelajaran terpadu berbasis budaya untuk meningkatkan apresiasi siswa terhadap budaya lokal Cakrawala Pendidik. 24 189-203

[5] Arthur J and Carr D 2013 Character in learning for life: A virtue-ethical rationale for recent research on moral and values education J. Beliefs Values 34 26-35

[6] A. Kamaruddin S 2014 Character Education and Students Social Behavior J. Educ. Learn. 6223

[7] Sanjaya D B and Divayana D G H 2015 An Expert System-Based Evaluation of Civics Education as a Means of Character Education Based on Local Culture in the Universities in Buleleng Int. J. Adv. Res. Artif. Intell. 4 17-21

[8] Prawiro A M B 2015 Reception of Islamic Law On Indigenous Communities: Study of Legal Anthropology in Baduy and Kampung Naga Kawalu J. Local Cult. 42-62

[9] Purwanto M R, Chotimah C and Mustofa I 2018 Sultan Agung's Thought of Javanis Islamic Calender and its Implementation for Javanis Moslem Int. J. Emerg. Trends Soc. Sci. 4 9-14

[10] Mulyana A 2017 Sekaten Tradition: The Ritual Ceremony in Yogyakarta as Acculturation Reality of Javanese Culture in Indonesia Int. J. Humanit. Soc. Sci. Stud. 450

[11] Foley K 2015 The Ronggeng, the Wayang, the Wali, and Islam: Female or Transvestite Male Dancers-Singers-Performers and Evolving Islam in West Java Asian Theatr. J.

[12] Franke E 2019 The Religious Language of Objects : What Semar Says about the Religious Culture of

[13] van den Boogert $\mathbf{J} 2017$ The role of slametan in the discourse on Javanese Islam Indones. Malay World 45 352-72

[14] Novita Siswayanti 2016 the roles of sendang duwur mosque as a form of cultural acculturation J. SMaRT 2 43-54

[15] Ibda H and Tengah J 2018 PENGUATAN NILAI-NILAI SUFISME DALAM 02 148-61 
[16] umi muzayanah 2016 domestic violence and the role of religious institutions in banyumas central java J. SMaRT Stud. Masy. Reli. dan Tradisi 02 199-211

[17] John J C and Ray D 2000 Citizenship for the 21st Century: An International Perspective (London: Cogan Page Limited)

[18] Beck U and Ritter M 1995 Ecological enlightenment: Essays on the politics of the risk society lavoisier.fr

[19] Budiyono B, Kokotiasa W, Harmawati Y and Feriandi Y A 2018 Social Cohesion in Society: A Study on Inter-Religious Harmony 1 157-65
[20] nasikun 2008 No Title (Rajawali Pers)

[21] J. S. Furnivall 2010 Netherlands India: A Study of Plural Economy (Cambridge Library Collection - East and South-East Asian History (Cambridge University Press)

[22] Agustin D 2011 Penurunan Rasa Cinta Budaya Dan Nasionalisme Generasi Muda Akibat Globalisasi J. Sos. Hum. 4 177-85 